\title{
Environmental resistance in the Anthropocene
}

\author{
OÑATI SOCIO-LeGAL SERIES Volume 10, Issue 6 (2020), 1317-1337: GOVERNING THE POlitiCAL: \\ LAW AND THE POLITICS OF RESISTANCE \\ DOI LINK: HTTPS://DOI.ORG/10.35295/OSLS.IISL/0000-0000-0000-1048 \\ RECEIVED 25 JULY 2018, ACCEPTED 10 DECEMBER 2018
}

\section{LYNDA M. COLLINS*}

\section{Abstract}

Scientists describe the current "Anthropocene epoch" as one of profound anthropogenic disruptions in the ecosphere that place humanity at an unacceptable risk. This unprecedented ecological moment in human history is rooted in profoundly unsustainable patterns of production and consumption protected by liberal power structures expressed through law. The exigencies of the Anthropocene call us to expand the subjects of resistance to include future generations of humans, plants, non-human animals, ecosystems and "non-living" natural entities (such as water, air and climatic systems). Since these constituencies cannot resist in a socio-political sense, their representation in current socio-political systems will depend upon "an insurrection of subjugated knowledges" (Foucault 1980, 81) including Indigenous law, pre-modern holistic traditions of Western legal thought, and emerging theories of ecological law. This article will explore these approaches as possible paths forward in the Anthropocene, employing a comparative law perspective that considers relevant jurisprudence and policy developments from around the globe.

\section{Key words}

Ecological law; Indigenous law; environmental governance; Anthropocene

\section{Resumen}

Los científicos describen la época antropocena actual como una época de profundas perturbaciones antropogénicas en la ecosfera, situando a la humanidad ante un peligro inaceptable. Este momento ecológico hunde sus raíces en modelos insostenibles de producción y consumo, protegidos por estructuras de poder liberales. Las exigencias del Antropoceno nos urgen a incluir entre los sujetos de la resistencia a generaciones futuras de humanos, plantas, animales no humanos, ecosistemas y entes

The author is grateful to Professors Carmela Murdocca and Laura J. Kwak, and to the anonymous reviewers for their helpful comments.

* Full Professor, Centre for Environmental Law \& Global Sustainability, University of Ottawa. 57 Louis Pasteur Street Ottawa, K1N 6N5 Canada. Phone: 613-562-5800 ex 2913. Email address: 1collins@uottawa.ca https://papers.ssrn.com/sol3/cf dev/AbsByAuth.cfm?per_id=1311333 
"no vivos" (como el agua, el aire y los sistemas climáticos). Como esas entidades no pueden ejercer resistencia en un sentido sociopolítico, su representación dependerá de "una insurrección de conocimientos subyugados" (Foucault 1980, 81), incluyendo leyes indígenas, tradiciones holísticas premodernas de pensamiento jurídico occidental y teorías jurídicas ecológicas emergentes. Este artículo examina tales enfoques, utilizando una perspectiva jurídica comparativa que toma en consideración jurisprudencia relevante y desarrollos de políticas en todo el mundo.

\section{Palabras clave}

Derecho ecológico; derecho indígena; gobernanza medioambiental; Antropoceno 


\section{Table of contents}

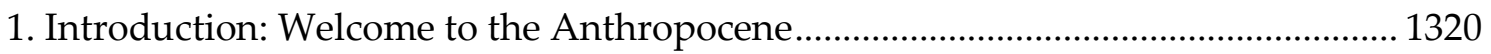

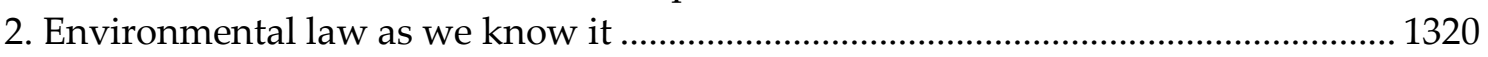

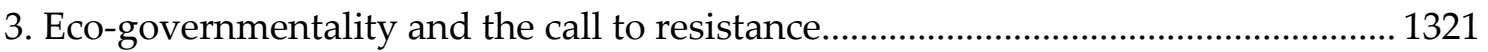

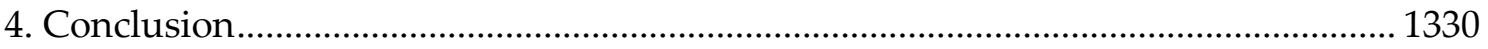

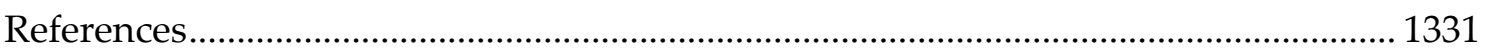

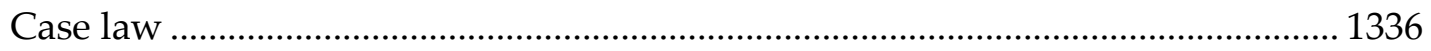




\section{Introduction: Welcome to the Anthropocene}

The present geological epoch, known by many in the scientific community as the "Anthropocene", is unprecedented in the history of Planet Earth (Davies 2016, Waters et al. 2016). Unlike past epochs, marked by natural shifts in climate or the organic rise and fall of key species, the Anthropocene is characterized by profound anthropogenic disruptions in the ecosphere (Edwards 2015, International Commission on Stratigraphy 2016). In short, our current modes of living, particularly in the developed world, are not sustainable over time (United Nations Environment Programme 2012). Fortunately, there are effective social, political and scientific solutions to most of the environmental problems we now face (Dauncey 2009). As we seek to shift the course of global history towards a sustainable future, our economic, social and legal systems will need to undergo a profound transformation (Kotzé 2014). In particular, environmental law needs to be radically re-imagined to account for the inescapable ecological realities that shape human experience. At the same time, affected communities and conscientious policymakers will need to make immediate use of existing environmental law and governance structures to slow down and, wherever possible, reverse ongoing environmental degradation.

This Article will analyze strategies for resisting the powerful drivers of unsustainability both within and outside of conventional paradigms of environmental law. Since the topic is immense, the author will focus on a few key examples of effective strategies of resistance through and to environmental law in its current form. The analysis begins with a brief overview of the current state of environmental law before canvassing the many forms of resistance to ecological harms that are occurring at every level of human society. In particular, I highlight three transformative avenues for resistance to our current inadequate systems of environmental law and governance: ${ }^{1}$ Indigenous law, the resurgence of Western ecological thought, and the emergence of a new paradigm of "ecological law".

\section{Environmental law as we know it}

While there is no question that conventional environmental law has done much to reduce pollution, it is equally clear that existing legal approaches have failed to secure a sustainable future (McNeill 2000, United Nations Environment Programme 2012). Despite its laudable aims, most environmental law around the world

is rooted in modern Western law with its origins in religious anthropocentrism, Cartesian dualism, philosophical individualism and ethical utilitarianism. In our ecological age, this worldview is out-dated and counterproductive, yet it continues to dominate the way environmental laws are conceived and interpreted. (Ecological Law and Governance Association 2016)

Indeed, the term "environment" itself arguably reflects the very intellectual delusion that has led to the ecological crisis we now face. Humans, and their legal systems, have conceptualized the natural world as something that surrounds us - our "environment" - when there is actually no separation between humans and the rest of the natural world.

\footnotetext{
${ }^{1}$ For an excellent explanation of the relationship between law and governance, see Orebech et al. 2005, Kotzé 2012, 995-998.
} 
We are biological beings, and because we are dependent on our relationships with other biological beings, ecosystems and ultimately the Earth as a whole, we are fundamentally ecological beings. "[A]t a primary level human society is a subset of the ecosphere" (Borrows 1997). Environmental law has failed to appreciate this crucial truth.

The voluminous scholarship on point reveals that environmental regulatory agencies in governments around the world are enormously complex, technocratic, isolated from each other and from ecological realities, jurisdictionally constrained, inaccessible to the non-expert public, and vulnerable to political and economic pressures that have no respect for non-negotiable ecological imperatives (Boyd 2003, Collins 2007, Wood 2013, Kotzé 2014). Environmental statutes are characterized by the pervasive presence of discretion and this discretion is habitually exercised in favour of economic interests as opposed to ecological sustainability. Indeed, Wood contends that "[t]he modern environmental administrative state is geared almost entirely to the legalization of natural resource damage (...). [T] he majority of agencies spend nearly all of their resources to permit, rather than prohibit, environmental destruction" (Wood 2009, 55). In fact, environmental law as we know it has presided over an unprecedented period of socio-ecological crisis (Kotzé 2014).

\section{Eco-governmentality and the call to resistance}

The neo-Foucauldian concept of eco-governmentality (while both contested and multidimensional) refers generally to the construction of the "environmental state" (Goldman 2001). This includes both the conceptual construction of the "environment" itself and the extension of governmental power into natural processes from a local to global scale, also known as "biopower" (de Lucia 2017, Hartman 2017). While environmental law represents an explicit attempt to control the environmental conditions in a given jurisdiction, the most profound environmental influence of governments is ironically found outside the realm of "environmental law" per se. In particular, as creator/guarantor of private rights in property, most notably the rights of corporations to engage in extractive and polluting activities, the state indirectly determines the basic biological parameters for its citizens' lives: e.g. the quality of air, drinking water, green space, food, etc. (Wood 2013, Simons and Macklin 2014). This is a striking incursion of state power into the lives of ordinary people. However, as Foucault $(1980,108)$ recognized, wherever populations are regulated "through subsuming life under the care of power", the possibility of resistance also arises (Foucault 1980 cited Valdivia 2015, 469).

Resistance to the ecological harms of the Anthropocene has taken innumerable forms, including informal local activism, coordinated international civil society movements, law reform (especially radical reforms by outlier states), and public interest litigation, to name just a few (Hawken 2008). Within existing legal systems, perhaps the most transformative vehicles for resistance are constitutional environmental rights (Boyd 2012a, Daly and May 2014, Gellers 2015). Particularly in regions that have created effective structures allowing citizens meaningful access to justice, constitutional litigation has the potential to create real environmental change. In an Indian case, for example, the Supreme Court ordered the City of Delhi to convert its huge fleet of diesel buses to compressed natural gas to ameliorate air quality and reduce pollution-related mortality and morbidity (Narain and Greenspan Bell 2005). In the Philippines, the 
judiciary has imposed detailed, ongoing and ambitious remedies resulting in massive remediation efforts that cleaned up the most polluted watershed in that nation (Manila $v$ Concerned Residents of Manila Bay, 2008). In a similar case out of Argentina concerning the highly polluted Matanza-Riachuelo river basin, the Supreme Court required government to conduct a comprehensive environmental assessment of the river, to inspect all polluting facilities, close illegal dumps, clean up the river banks, improve the storm water, sewage and wastewater systems, and develop a regional environmental health plan (Beatriz Silvia Mendoza el al. $v$ National State of Argentina et al., 2008). Hundreds of thousands of people now enjoy access to safe drinking water and sanitation as a result of these judgments (Boyd 2012b, 94).

Constitutional environmental rights have also been mobilized to address government inaction in the face of climate change. This is a particularly transformative avenue for resistance since it provides activists with an opportunity to protect future generations, whose interests are woefully under-represented in conventional environmental law. In the 2015 Urgenda case, brought by a civil society organization, a Dutch court ordered the state to reduce greenhouse gas emissions by a minimum of $25 \%$ by 2020 , based on Dutch constitutional and legal obligations to preserve the environment (Urgenda $v$ The Netherlands, 2015). The decision was upheld on appeal in 2018 (The Netherlands v Urgenda, 2018). In similar litigation in Pakistan, the High Court ordered the Pakistani government to implement its national climate change policy, noting that the threat posed by climate change calls for judicial "protection of fundamental rights of the citizens of Pakistan, in particular, the vulnerable and weak segments of the society who are unable to approach this Court" (Ashgar Leghari v Pakistan, 2015).

In some jurisdictions, litigants have argued successfully that environmental interests are in fact implicit in all constitutions (and all areas of human endeavour). The Supreme Court of the Philippines eloquently captured this idea in its celebrated decision in Minors Oposa, a case concerning the environmental rights of future generations:

While the right to a balanced and healthful ecology is to be found under the Declaration of Principles and State Policies and not under the Bill of Rights, it does not follow that it is less important than any of the civil and political rights enumerated in the latter. Such a right belongs to a different category of rights altogether for it concerns nothing less than self-preservation and self-perpetuation[,] the advancement of which may even be said to predate all governments and constitutions. As a matter of fact, these basic rights need not even be written in the Constitution for they are assumed to exist from the inception of humankind. (Minors Oposa $v$ Secretary of the Department of Environmental and Natural Resources, 1993, 187, cited Atapattu 2002, 106-107)

The US District Court for the District of Oregon cited Oposa when denying a motion to dismiss the recent lawsuit brought by a coalition of young people who argue that government inaction on climate change has violated their right to "substantive due process" (Juliana $v$ United States, 2016). In holding that a stable climate might constitute an "un-enumerated fundamental right", the Court recognized that "a stable climate system is quite literally the foundation 'of society, without which there would be neither civilization nor progress'” (Juliana v United States, 2016). ${ }^{2}$

\footnotetext{
2 Internal citations omitted.
} 
In sum, constitutional environmental rights allow citizens to disrupt environmental-lawas-usual by seeking judicial protection for a minimum environmental quality of life. Such trans-legislative approaches to environmental governance are less likely to be constrained by the bureaucratic inertia and conflicted mandates that have impaired the efficacy of administrative environmental law. The next three sections address more fundamental alternatives to environmental law as we have known it.

i) Indigenous law

As Borrows has noted, "[Indigenous] knowledge has often been delegitimated and thus concealed from wider public view. So-called 'democratic' institutions repress Indigenous participation, degrade their environments, and thereby hinder the extension of knowledge about how to coexist with the environment" (Borrows 1997, 425). In many ways, then, Indigenous law epitomizes the Foucauldian notion of "subjugated knowledges" (Foucault 1980, 81-82). ${ }^{3}$ The whole colonial project is founded on the erasure of Indigenous legal interests in lands and waters and the transformation of a living Earth into "property" within the Western legal understanding (Lindberg 2015). Thus, one powerful form of environmental resistance is the reanimation and recognition of Indigenous law. Obviously the most radical vision for change in this area would be the return of Indigenous self-government, according to Indigenous law, in all territories that can be shown to belong to any Indigenous group. This is a long-term project that may or may not be achievable given the geopolitical and economic realities of our current historic moment. However, even in the difficult context of ongoing colonialism, Indigenous law can find space in which to affect our collective environmental trajectory. This can be accomplished in a variety of ways.

First, Indigenous law can be articulated and applied in spaces in which Indigenous peoples enjoy meaningful self-determination, either within or outside of formal state structures. Indigenous peoples can and do use their existing environmental legal principles to regulate their own conduct as individuals and groups. For example, most Indigenous groups view certain areas as sacred and regulate permitted and prohibited conduct by their members in these sacred sites (Burton 2002, Ross 2005, Verschuuren et al. 2010). As one Canadian Indigenous advocate has noted, traditional sources of Indigenous law, including stories and spiritual beliefs, can function as highly effective mechanisms of environmental law/governance:

In Indigenous legal systems, Creation stories are often crucial. They explain how we got here, how we relate to the land and to other living things, and what our responsibilities are. The stories are law. They do what law does: they regulate behaviour. [Indigenous] 'beliefs' about what is allowed in [sacred sites] have been as effective, in terms of what people have done there (...) for thousands of years, as any zoning by-law, or any provincial land use law. (Williams 2017)

\footnotetext{
3 “By 'subjugated knowledges' one should understand (...) a whole set of knowledges that have been disqualified as inadequate to the task or insufficiently elaborated; naive knowledges, located low down on the hierarchy, beneath the required level of cognition or scientificity. I also believe that it is through the reemergence of these low-ranking knowledges, these unqualified, even directly disqualified knowledges (...) a differential knowledge incapable of unanimity and which owes its force solely to the harshness with which it is opposed by everything surrounding it - that criticism performs its work."
} 
In addition to this internal self-regulation in environmental matters, Indigenous law can also guide activism efforts by Indigenous peoples and their allies. ${ }^{4}$

In some jurisdictions, domestic (i.e. colonial) law has carved out discrete areas of Indigenous self-determination, in which Indigenous law can actually determine environmental outcomes. In such cases, colonial courts can function as allies to Indigenous environmental decision-makers. In Wisconsin v EPA (2001), for example, the State of Wisconsin challenged the federal Environmental Protection Agency's devolution of regulatory power over water quality on reserve to a Chippewa Indigenous group. The Seventh Circuit Court of Appeal upheld the Chippewa's right to regulate water quality on its reservation, including the right to set higher standards than those in place at the state level. The Court held that, "[b]ecause the Band has demonstrated that its water resources are essential to its survival, it was reasonable for the EPA, in line with the purposes of the Clean Water Act (...) to allow the tribe to regulate water quality on the reservation, even though that power entails some authority over off-reservation activities" (Wisconsin v EPA, 2001).

Some ten years after Wisconsin $v E P A$, the Supreme Court of India recognized an Indigenous group's right to regulate resource extraction in its traditional territory in Orissa Mining Corp. Ltd. v Ministry of Environment and Forest, et al. (2013). In that case the Supreme Court enforced provisions of the Forest Rights Act granting tribal peoples customary rights over their traditional territories. The case concerned a proposed bauxite mine in the "Niyamgiri", an area considered sacred by the local Dongria Kondh Indigenous people. After a number of illegal acts, including the failure to obtain consent from the Dongria Kondh, the proponent was denied the necessary permits and appealed to the courts. In 2013, the Supreme Court ordered the state government to seek consent for the proposed mine by referring the decision to the gram sabhas (or village councils) of the affected Indigenous communities (Menon 2015). As Menon $(2015,10658)$ explains: "every village of the 12 consulted rejected the proposal for mining. All villages unanimously resolved that the Niyamgiri, the abode of their god, was to be protected and that no permission for mining could be issued". The Ministry therefore rejected the company's application.

In a few jurisdictions around the world, Indigenous peoples have achieved access to mainstream political power, allowing Indigenous law to be "codified" and effectuated at the national level. In both Ecuador and Bolivia, for example, formal enactments have recognized that Nature itself enjoys legally cognizable rights, in keeping with the Indigenous laws of those territories. The Constitution of Ecuador (2008, article 71) provides that "Nature, or Pachamama, where life is reproduced and created, has the right to integral respect for her existence, her maintenance and for the regeneration of her vital cycles, structure, functions and evolutionary processes." In Wheeler c. Director de la Procuraduría General del Estado de Loja (2011), the Ecuadorian Court held that the precautionary principle applies to claims under this provision and there is a presumption in favour of the rights of Nature:

\footnotetext{
4 See Lovelace $v$ Ontario (2000). This is a case concerning the prosecution of Indigenous activist Robert Lovelace for continuing peaceful protest against uranium prospecting in his nation's traditional territory despite a court injunction against it. In reducing his sentence, the Ontario Court of Appeal noted that Professor Lovelace was following his own Algonquin law in opposing uranium prospecting.
} 
[U]ntil it can be shown that there is no probability or danger to the environment of the kind of work that is being done in a specific place, it is the duty of constitutional judges to immediately guard and to give effect to the constitutional right of nature, doing what is necessary to avoid contamination or to remedy it. (Wheeler c. Director de la Procuraduría General del Estado de Loja 2011, Daly 2012)

In New Zealand, years of education, activism and negotiation have led to real political power for the Maori Indigenous people culminating in statutory recognition of the legal personhood (and rights) of the Whanganui River and a former national park known as "Te Urewera". When the Whanganui River Claims Settlement Act (2017) was passed, lead negotiator for the Whanganui iwi [tribe], Gerrard Albert, explained: "[W]e consider the river an ancestor and always have (...). We have fought to find an approximation in law so that all others can understand that from our perspective treating the river as a living entity is the correct way to approach it (...)" (Roy 2017). Similarly, the Te Urewera Act (2014) recognized the legal personhood of that area of land, creating a cooperative comanagement scheme involving both Crown and Maori representation.

Finally, even in areas where Indigenous law has not been recognized through binding legal enactments, judges around the world have the power to recognize and apply Indigenous law, policy and science as they adjudicate environmental disputes of many kinds. While there are certainly pitfalls in non-Indigenous judges (appointed by nonIndigenous governments) interpreting and attempting to articulate Indigenous law, it seems clear that respectful engagement is highly preferable to the current state of affairs in which Indigenous law is most often simply ignored by colonial courts. As Borrows has argued, the adoption of Indigenous law enriches the legal tool kit for environmental protection, appropriately posits Indigenous peoples as legal subjects and entails a paradigm shift away from modes of thought that have produced the Anthropocene and towards philosophical and legal structures that have the potential to support a sustainable inter-species community on Earth (Borrows 1996, 1997, 2010). Thus, "[Indigenous] knowledge must be considered and received as precedent in law to guide answers to the questions we have concerning the environment" (Borrows 1997, 452). ${ }^{5}$

In order to seek guidance from Indigenous law on the questions at issue in environmental litigation, courts will often need to revisit and revise long-established rules of evidence, as Canadian courts have done since the landmark decision in Delgamuukw v British Columbia (1997, 84-87), where the Supreme Court of Canada accepted that oral histories could be evidence of Aboriginal title. Henderson has opined that Delgamuukw and its progeny "ended the legal dialectic between the familiar English system and the exoticized Aboriginal difference" in Canada (Youngblood Henderson et al. 2000, 8). More recently, the Supreme Court of Canada evinced an understanding and respect for Indigenous law by recognizing that the environmental rights of Aboriginal title-holders include an intergenerational component. In Tsilhqot'in Nation $v$ British Columbia (2014, para. 86), the Court held that "incursions on Aboriginal title cannot be justified if they would substantially deprive future generations of the benefit of the land", and further that Aboriginal title lands cannot be put to uses that would "destroy

\footnotetext{
${ }^{5}$ While it is important to avoid romantic stereotypes that may essentialize or constrain Indigenous peoples, there is no doubt much to be learned from historic and contemporary Indigenous approaches to environmental protection (see Richardson 2009).
} 
the ability of the land to sustain future generations of Aboriginal peoples" (Delgamuukw $v$ British Columbia, 1997, para. 166 cited Tsilhqot'in Nation v British Columbia, 2014, para. 121). The notion of a binding intergenerational obligation of ongoing sustainability is otherwise absent from Canadian law but is an organizing principle in Indigenous legal traditions in the territory now known as Canada (see eg Little Bear 1996). Thus, the Court would appear to be giving effect to Indigenous law in this breakthrough decision.

Because Indigenous law is inseparable from Indigenous culture, spirituality, and scientific knowledge, courts seeking to give effect to the "subjugated knowledges" of Indigenous peoples will also need to reach well beyond legal principles that would be easily recognizable to the post-modern Western mind. For example, spiritually-based land use planning and environmental protection law may sit uneasily with secularobsessed Western legal systems. ${ }^{6}$ However, it is possible even for Western adjudicators to make the necessary cognitive leap (Bakht and Collins 2017). The decision of a New Zealand court concerning river diversions in Indigenous territory demonstrates this cross-cultural "bridging" well:

The most damaging effect of [the] diversions on Maori has been on the wairua or spirituality of the people. Several of the witnesses talked about the people "grieving" for the rivers. One needs to understand the culture of the Whanganui River iwi [tribe] to realise how deeply ingrained the saying ko au te awa, ko te awa, ko au [I am the river, the river is me] is to those who have connections to the river (...). Their spirituality is their 'connectedness' to the river. To take away part of the river (...) is to take away part of the iwi. To desecrate the water is to desecrate the iwi. To pollute the water is to pollute the people. (Ngati Rangi Trust v Manawatu-Wanganui Regional Council, 2004, para. 109, 318, 320 cited in Magallanes 2015)

Indeed, New Zealand courts have frequently prohibited development based on the subjugated knowledges of its Indigenous peoples concerning appropriate behaviour in particular areas. Magallanes $(2015,280)$ elaborates:

Cases rejecting (...) interference [with Maori sacred sites] have concerned a wide range of matters, including the discharge of sewage effluent into the sea, the location of a road being too close to old burial sites, a television aerial being too close to and thereby interfering with Maori metaphysical relationships with a battle site, and a wind farm being too close to - and interfering with Maori metaphysical relationships with - a mountain of spiritual significance. (Magallanes 2015) ${ }^{7}$

The land-based spiritual rights of Indigenous peoples have also been recognized in regional human rights venues, in particular at the Inter-American Court of Human Rights. In its decision upholding Indigenous property rights in Sarayaku v Ecuador (2012, para. 155), the Court paid close attention to the Sarayaku's "profound and special relationship with their ancestral territory, which is not limited to ensuring their subsistence, but rather encompasses their own worldview and cultural and spiritual

\footnotetext{
6 The Supreme Court of Canada, for example, evinced its discomfort with spiritually-based land use planning when it failed utterly to respect Indigenous law relevant to developments on sacred sites in the case of Ktunaxa Nation v British Columbia (Forests, Lands and Natural Resource Operations) [2017] 2 SCR 386. See also Bakht and Collins 2017.

${ }^{7}$ Internal citations omitted.
} 
identity" ${ }^{8}$ In its earlier decision in Saramaka v Suriname (2007, para. 200-201), the Court awarded US $\$ 600,000$ to an Indigenous group for intangible damages caused by environmentally destructive logging that interfered with the group's "spiritual connection" to their territory, resulting in a "denigration of their basic cultural and spiritual values." The Court held that this intangible "damage caused to the Saramaka people by these alterations to the very fabric of their society entitles them to a just compensation" (Case of the Saramaka People v Suriname 2007). While one can reasonably question whether any amount of money damages is capable of redressing spiritual injury, this judgment evinces real respect for Indigenous spiritual rights in land.

To summarize, the resurgence and reanimation of Indigenous law poses a fundamental challenge to environmental law as we have known it and presents an unprecedented opportunity to change the course of global environmental history.

ii) The resurgence of Western ecological thought

Although Western modes of thought and practice have justly been blamed for creating the legal, socio-political and economic structures that are arguably at the root of the Anthropocene problem, Western history is rich with ecological thought. The prepatriarchal, pre-Christian culture of Europe was undoubtedly steeped in an intimate understanding of, and relationship with, Nature. ${ }^{9}$ No doubt much of this pre-Cartesian history has been lost, but even among canonical Western traditions, a vein of ecological thought is discernible (Wacke 2002). Ancient Greek philosophy, for example, "viewed the world as a kosmos, an ordered and harmonious structure, more a living organism rather than a mechanical system" (Capra and Mattei 2015, 31).

Within European Christianity, St. Francis of Assisi exemplifies the ecological consciousness. Pope Francis describes his namesake in the groundbreaking papal encyclical Laudato si:

Francis helps us to see that an integral ecology calls for openness to categories which transcend the language of mathematics and biology, and take us to the heart of what it is to be human. Just as happens when we fall in love with someone, whenever he would gaze at the sun, the moon or the smallest of animals, [St. Francis] burst into song, drawing all other creatures into his praise. He communed with all creation (...). His response to the world around him was so much more than intellectual appreciation or economic calculus, for to him each and every creature was a sister united to him by bonds of affection. (Francis, the Holy Father 2015)

Ecological thinking also has roots in the legal traditions of the West. The public trust doctrine, or the notion that government holds navigable waters in trust for present and future citizens, dates back to Roman law under Justinian, and survived into both French civil law and English common law in the medieval period (de Bracton 1968, MacGrady 1975). On land, ecological interests were recognized in the foundational codification of

\footnotetext{
8 Indeed, the Court engages deeply and specifically with the particular land-based religious beliefs of the Indigenous claimants, mentioning for example that while the Sarayaku consider the entire territory sacred, the oil exploration had specifically interfered with sites of special spiritual significance, including through the destruction of a sacred tree named Lispungu (Kichwa Indigenous People of Sarayaku v Ecuador, 2012, para. 104, 127, 148-155).

9 See generally, Jones and Pennick 1995. See also, Capra and Mattei 2015, 4 (“Until the Middle Ages, cultures around the world observed nature very closely and adapted their way of life accordingly").
} 
human rights in the West. The Charter of the Forest of 1217 guaranteed to British subjects rights of access to vital natural resources, which reinforced the civil and political rights contained in its companion document, the Magna Carta (Blackstone 1759). The Charter of the Forest "represented an early, though failed, attempt to protect peasants' equal access to nature and its gifts of water, food, fuel and shelter, against centralized extractive control, both private (by the barons) and public (by the king)" [Capra and Mattei 2015, 53].

As Capra and Mattei (2015) recount in their brilliant book The Ecology of Law, the ensuing centuries witnessed an unprecedented move away from ecological living and towards socio-political and economic systems that were divorced from the biological bottom line of being human. The thinking of Descartes, Bacon and Newton transformed nature from a sacred living being to a machine to be manipulated and subdued for human ends. The rule of law developed as a mechanism to protect state sovereignty on the one hand and private property on the other, leaving little space for ecological (or indeed social) commons. The Romantic movement of the late $18^{\text {th }}$ and early $19^{\text {th }}$ centuries "stood in opposition to the mechanistic worldview of Newtonian science and Enlightenment philosophy", but by then the momentum of private property, state sovereignty, capitalism and colonialism was unstoppable (Capra and Mattei 2015, 87). As technology improved exponentially over time, the extractive Western economy became increasingly unsustainable (and globalized), bringing us to the current state of affairs (McNeill 2000). However, ecological consciousness is being rediscovered throughout the Western world.

The resurgence of ecological thought in the West is evident in a wide variety of social, intellectual and legal movements including grassroots environmentalism, the back-tothe-land movement, the development of green political theory (such as deep ecology and ecofeminism), and a growing recognition of the rights of nature in local law and governance (in addition to the important developments in Ecuador and Bolivia mentioned above). Since 2006, more than thirty local governments in the US have drafted local ordinances recognizing the rights of nature (Community Environmental Legal Defense Fund 2018). With the help of the NGO Community Environmental Legal Defense Fund, these local groups are mobilizing their rights of nature laws to oppose fracking, toxic dumping, and other unsustainable practices. Efforts are ongoing to bring rights of nature to the state level in the US (Community Environmental Legal Defense Fund 2018).

The UK has made its first forays into rights of nature, with a proposed by-law in the town of Frome providing that:

The River Frome shall have the right to exist, the right to water, the right to natural flows and sustainable recharge sufficient to protect habitat for native flora and fauna, the right to maintain the functionality of the water cycle in the quantity and quality needed to sustain and restore a thriving healthy ecosystem in all its forms, the right to flourish and thrive and the right to timely and effective restoration (...). [Frome Town Council 2016]

In summary, it is clear that ecological consciousness has survived in the West and is reemerging into legal discourse.

At the confluence of the Western ecological comeback, the resurgence of Indigenous law, and the evolution of sustainable development policy in the Global South (United 
Nations 2015), a new paradigm of "ecological law" has emerged as an alternative to existing systems of environmental law around the world.

\section{iii) Ecological Law}

Advocates of ecological law argue that, given the very serious failure of our current systems of environmental law, there is an urgent need for transformative, re-theorized legal systems that take account of the irreducible ecological prerequisites for human survival. The emerging theory of "ecological law" (Garver 2013, Woolley 2014) [also known as "green legal theory" (M'Gonigle and Takeda 2013, Weston and Bollier 2013), "sustainability law" (Boyd 2004), and "wild law" (Cullinan 2011)] suggests that what is needed is a fundamental restructuring of human relationships with the Earth, one that recognizes our inextricable interdependence with the rest of the natural world. Ecological law is an emerging area of theory and practice. Its current state of the art is perhaps best captured by the Oslo Manifesto, which recently gave birth to the Ecological Law and Governance Association. The Oslo Manifesto maps out a radical agenda for transformation in the legal relationship between humans and the rest of the natural world:

To overcome the flaws of environmental law, mere reform is not enough. We do not need more laws, but different laws from which no area of the legal system is exempted. The ecological approach to law is based on ecocentrism, holism, and intra/intergenerational and inter-species justice. From this perspective, or worldview, the law will recognise ecological interdependencies and no longer favour humans over nature and individual rights over collective responsibilities. Essentially, ecological law internalises the natural living conditions of human existence and makes them the basis of all law, including constitutions, human rights, property rights, corporate rights and state sovereignty. (Ecological Law \& Governance Association 2016)

Ecological law thinkers seek the transformation of every aspect of existing systems of environmental law, from legal pedagogy (which should immerse students in the outdoors and encourage them to develop their sensory and emotional connection with nature) [Cullinan 2011], to the process of creating law (which should involve broadbased public deliberation including the perspectives of marginalized populations, notably Indigenous peoples) [Woolley 2014], to the substance of the laws themselves. Because ecological law is inherently holistic, it must be expressed at every level of a legal system, and should be recognized and enforced by all legal decision-makers, including legislators, regulators, and adjudicators.

While a detailed description of the substantive content of ecological legal systems would merit its own lengthy volume (eg Bosselmann and Taylor 2017), key principles and practices are becoming clear. In an ecological legal order, governments and communities need to regulate ecological realities rather than legal fictions. Thus, for example, pollution regulations should include the assessment of cumulative emissions and binding ambient standards (i.e. standards that put a hard cap on pollutant levels in air and water) rather than regulating specific "point sources" as if they existed in isolation (Collins 2013). The ecological law paradigm also recognizes the need to be cautious (or even sceptical) about our ability to predict the impacts of human activity on complex and dynamic ecological systems (Thornton 2000, Wood 2013). 
Ecological law thinking embraces the "precautionary principle" and challenges the technocratic paradigm of "resource management" (Collins 2013). Thus, rather than believing that we can successfully manage a forest, lake or fishery, we need to recognize that those systems are self-managing and the best thing we can do for them is to get out of the way (Cullinan 2011). While this is an impossible aim in many cases, a frank recognition of difficulties of prediction in ecology has several clear and achievable policy implications. First, as Olivia Woolley has argued in her pivotal book Ecological Governance, we should implement a policy in favour of preserving ecological resilience and we should assume that any stressors introduced by human activity tend to undermine such resilience (Woolley 2014). Second, because natural systems function best when human impacts are minimized, ecological law requires a significant portion of territory to be preserved in protected areas, in which commercial-scale extractive activities are prohibited. ${ }^{10}$

In the area of chemicals regulation, ecological law would take a similarly precautionary approach, adopting the principles of clean production, zero discharge, and reverse onus. Clean Production mandates a shift from our current focus on pollution control to a proactive and precautionary rule favoring pollution prevention; it requires that industry make use of the most benign available methods and materials and seek to prevent the release of hazardous materials by preventing their production in the first place (Thornton 2000, 348). The policy of zero discharge prohibits absolutely the release of persistent and/or bio-accumulative chemicals (Thornton 2000, 347-348). Reverse onus would invert current regulatory policy by requiring proponents of synthetic chemicals to demonstrate their safety before being permitted to produce and release them (Thornton 2000, 346, Fitzmaurice et al. 2010).

Additional features that would characterize an ecological legal order include the public trust doctrine, constitutional recognition of the rights of Nature, legislative recognition of the legal personhood of natural ecosystems and features (e.g. forests, rivers) and intergenerational time horizons in rulemaking and public planning. Ecological law scholars have also stressed the crucial importance of empowering an ecologically literate citizenry to participate fully in ecological decision-making. This can be facilitated (in part) by the promulgation and enforcement of constitutional environmental rights in all nations. We are already seeing citizens in countries around the globe mobilizing their constitutional right to a healthy environment and/or constitutional rights of nature, to overturn inadequate government regulation and, indirectly, to hold private polluters to account (Boyd 2012a). Perhaps most fundamentally, an ecological legal order will prioritize the interests of living legal persons (be they human or non-human) over the inanimate corporation.

\section{Conclusion}

The urgency of the Anthropocene calls for a deep reimagining of the environmental state. Within existing environmental law structures, the most transformative is likely the mechanism of constitutional environmental rights. Such rights have been successfully

\footnotetext{
${ }^{10}$ The creation of such protected areas must obviously respect the land rights of Indigenous peoples and should not disproportionately exclude Indigenous peoples from economic opportunities available to nonIndigenous counterparts.
} 
mobilized around the world to disrupt harmful environmental policies and practices and to restore damaged ecosystems. Beyond the realm of existing environmental rights, the author has presented three possible avenues for resisting environmental law as we know it and creating the possibility of long-term sustainability: Indigenous law, the resurgence of ecological thought in the West, and ecological law.

Indigenous legal systems have millennia of experience in preserving respectful relations between humans and other members of the ecological community and should be viewed as an important level of ecological governance. In addition, Western legal thinkers and activists should encourage the trend towards an ecological resurgence in Western legal culture. As communities in Europe and North America return to deeply rooted ecological principles and practises, it is possible that the West can "find its way home again" in time to prevent irreversible global harm. Finally, the emerging field of ecological law has begun to articulate specific principles and practices that can offer us a real alternative to the inadequate environmental law structures of the past (and present). Scholars, students, and policy-makers should pay close attention to developments in ecological law thinking and seek to operationalize them at every opportunity.

In summary, as we seek to preserve and sustain vibrant human societies indefinitely into the future, we will need to begin by finding ways to resist environmental harm both through existing legal machinery and through the development of transformative new approaches such as those outlined above.

\section{References}

Atapattu, S., 2002. The Right to Life or the Right to Die Polluted?: The Emergence of a Human Right to a Healthy Environment Under International Law. Tulane Environmental Law Journal [online], 16(1), 65-126. Available from: https://www.jstor.org/stable/43292777 [Accessed 11 December 2018].

Bakht, N., and Collins, L., 2017. The Earth is Our Mother: Freedom of Religion and the Preservation of Aboriginal Sacred Sites in Canada. McGill Law Journal [online], 62(3), 777-812. Available from: https://doi.org/10.7202/1042774ar [Accessed 11 December 2018].

Blackstone, W., 1759. The Great Charter and Charter of the Forest. Oxford: Clarendon Press.

Borrows, J., 1996. With or Without You: First Nations Law (in Canada). McGill Law Journal [online], 41, 629-665. Available from:

https://www.aboriginallegal.ca/assets/withorwithoutyou.pdf [Accessed 11 December 2018].

Borrows, J., 1997. Living Between Water and Rocks: First Nations, Environmental Planning, and Democracy. University of Toronto Law Journal [online], 47(4), 417468. Available from: https://doi.org/10.2307/825948 [Accessed 11 December 2018].

Borrows, J., 2010. Canada's Indigenous Constitution. University of Toronto Press.

Bosselmann, K., and Taylor, P., 2017. Ecological Approaches to Law. Cheltenham: Edward Elgar. 
Boyd, D.R., 2003. Unnatural Law: Rethinking Canadian Environmental Law and Policy. Vancouver: UBC Press.

Boyd, D.R., 2004. Sustainability Law: (R)evolutionary Directions for the Future of Environmental Law. Journal of Environmental Law and Practice, 14, 357-385.

Boyd, D.R., 2012a. The Environmental Rights Revolution: A Global Study of Constitutions, Human Rights, and the Environment. Vancouver: UBC Press.

Boyd, D.R., 2012b. The Right to a Healthy Environment. Vancouver: UBC Press.

Burton, L., 2002. Worship and Wilderness: Culture, Religion, and Law in Public Lands Management. Madison: University of Wisconsin Press.

Capra, F., and Mattei, U., 2015. The Ecology of Law: Towards a Legal System in Tune with Nature and Community. Oakland: Berrett-Koehler.

Collins, L., 2007. Tort, Democracy and Environmental Governance: Crown Liability for Environmental Non-Enforcement. Tort Law Review, 15(2), 107-126.

Collins, L.M., 2013. Security of the person, peace of mind: a precautionary approach to environmental uncertainty. Journal of Human Rights and the Environment, 4(1), 79100.

Community Environmental Legal Defense Fund, 2018. Advancing Legal Rights of Nature: Timeline [online]. Available from: https://celdf.org/rights/rights-of-nature/rightsnature-timeline/ [Accessed 14 July 2018].

Constitution of the Republic of Ecuador, 2008 [online]. Article 71. Available from: http://pdba.georgetown.edu/Constitutions/Ecuador/english08.html [Accessed 14 July 2018].

Cullinan, C., 2011. Wild Law: A Manifesto for Earth Justice. $2^{\text {nd }}$ ed. White River Junction: Chelsea Green.

Daly, E., 2012. The Ecuadorian Exemplar: The First Ever Vindications of Constitutional Rights of Nature. Review of European, Comparative \& International Environmental Law [online], 21(1), 63-66. Available from: https://doi.org/10.1111/j.14679388.2012.00744.x [Accessed 11 December 2018].

Daly, E., and May, J.R., 2014. Global Environmental Constitutionalism. Cambridge University Press.

Dauncey, G., 2009. The Climate Challenge: 101 Solutions to Global Warming. Gabriola: New Society.

Davies, J., 2016. The Birth of the Anthropocene. Oakland: University of California Press. de Bracton, H., 1968. On the Laws and Customs of England (vol. 2). Cambridge: Belknap Press, 39-40.

de Lucia, V., 2017. Critical Environmental Law and the Double Register of the Anthropocene: A Biopolitical Reading. In: L.J. Kotzé, ed., Environmental Law and Governance for the Anthropocene. Oxford: Hart, 97-116. 
Ecological Law \& Governance Association, 2016. Oslo Manifesto for Ecological Law and Governance [online]. Available from: https://www.elga.world/oslo-manifesto/ [Accessed 13 July 2018].

Edwards, L., 2015. What is the Anthropocene? Eos [online], 30 November. Available from: https://doi.org/10.1029/2015EO040297 [Accessed 8 July 2018].

Fitzmaurice, M., Ong, D., and Merkouris, P., eds., 2010. Research Handbook on International Environmental Law. Cheltenham: Edward Elgar.

Foucault, M. (with C. Gordon, ed.,) 1980. Power/Knowledge: Selected interviews and other writings, 1972-1977. Trans.: C. Gordon et al. New York: Pantheon Books.

Francis, the Holy Father, 2015. Encyclical Letter on Care for Our Common Home [online]. Available from:

http://w2.vatican.va/content/francesco/en/encyclicals/documents/papafrancesco 20150524 enciclica-laudato-si.html [Accessed 14 July 2018].

Frome Town Council, 2016. River Frome and Rodden Meadow Byelaw [online]. Available from:

https://drive.google.com/file/d/1qnnpA3A2sEKamJ6yJQPKO99e1F3JuFU9/view [Accessed 14 July 2018].

Garver, G., 2013. The Rule of Ecological Law: The Legal Complement to Degrowth Economics. Sustainability [online], 5(1), 316-337. Available from: https://doi.org/10.3390/su5010316 [Accessed 11 December 2018].

Gellers, J., 2015. The Global Emergence of Constitutional Environmental Rights. London: Routledge.

Goldman, M., 2001. Constructing an Environmental State: Ecogovernmentality and other transnational practices of a "green" World Bank. Social Problems, 48(4), 499_ 523.

Hartman, S., ed., 2017. Contesting Environmental Imaginaries: Nature and Counternature in a Time of Global Change. Leiden: Brill/Rodopi.

Hawken, P., 2008. Blessed Unrest: How the Largest Social Movement in History is Restoring Grace, Justice and Beauty to the World. New York: Penguin.

Hay, P.R., 2002. Main Currents in Western Environmental Thought. Sydney: UNSW Press.

International Commission on Stratigraphy, 2016. International Chronostratigraphic Chart [online]. Available from: http://www.stratigraphy.org/index.php/ics-charttimescale [Accessed 26 April 2016].

Jones, P., and Pennick, N., 1995. A History of Pagan Europe. New York: Routledge.

Kotzé, L.J., 2012. Global Environmental Governance: Law and Regulation for the 21st Century. Cheltenham: Edward Elgar.

Kotzé, L.J., 2014. Rethinking Global Environmental Law and Governance in the Anthropocene. Journal of Energy \& Natural Resources Law [online], 32(2), 121-156. Available from: https://doi.org/10.1080/02646811.2014.11435355 [Accessed 11 December 2018]. 
Lindberg, T., 2015. Critical Indigenous Legal Theory Part I: The Dialogue Within. Canadian Journal of Women and the Law [online], 27(2), 224-247. Available from: https://doi.org/10.3138/cjwl.27.2.224 [Accessed 11 December 2018].

Little Bear, L., 1996. Relationship of Aboriginal People to the Land and the Aboriginal Perspective on Aboriginal Title. For Seven Generations: An Information Legacy of the Royal Commission on Aboriginal Peoples. [CD-ROM]. Ottawa: Minister of Supply and Services.

M'Gonigle, M., and Takeda, L., 2013. The Liberal Limits of Environmental Law: A Green Legal Critique. Pace Environmental Law Review [online], 30(3), 1005-1115 at

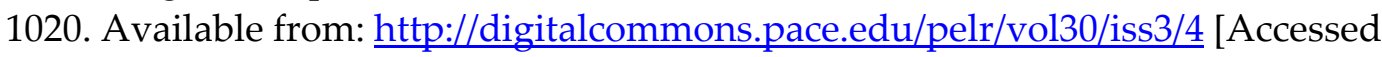
11 December 2018].

MacGrady, G.J., 1975. The Navigability Concept in the Civil and Common Law: Historical Development, Current Importance, and Some Doctrines That Don't Hold Water. Florida State University Law Review [online], 3(4), 511-615. Available from: http://ir.law.fsu.edu/lr/vol3/iss4/1 [Accessed 11 December 2018].

Magallanes, C.I., 2015. Maori Cultural Rights in Aotearoa New Zealand: Protecting the Cosmology that Protects the Environment. Widener Law Review [online], 21(2), 273-327. Available from: http://widenerlawreview.org/files/2008/10/15Magallanes.pdf [Accessed 11 December 2018].

McNeill, J.R., 2000. Something New Under the Sun: An Environmental History of the Twentieth-Century World. New York: WW Norton \& Co.

Menon, M., 2015. India's First Environmental Referendum: How Tribal People Protected the Environment. Environmental Law Reporter [online], 45(7), 1065610658. Available from: https://elr.info/news-analysis/45/10656/indias-firstenvironmental-referendum-how-tribal-people-protected-environment [Accessed 11 December 2018].

Narain, U., and Greenspan Bell, R., 2005. Who Changed Delhi's Air? The Roles of the Court and the Executive in Environmental Policymaking. Washington, DC: Resources for the Future.

Orebech, P., et al., 2005. The Role of Customary Law in Sustainable Development. Cambridge University Press.

Richardson, B.J., 2009. The Ties that Bind: Indigenous Peoples and Environmental Governance. In: B.J. Richardson, S. Imai and K. McNeil, eds., Indigenous Peoples and the Law: Comparative and Critical Perspectives. Oxford: Hart, 337-370.

Ross, M.L., 2005. First Nations Sacred Sites in Canada's Courts. Vancouver: UBC Press.

Roy, E.A., 2017. New Zealand river granted same legal rights as human being. The Guardian [online], 16 March. Available from: https://www.theguardian.com/world/2017/mar/16/new-zealand-river-grantedsame-legal-rights-as-human-being [Accessed 14 July 2018].

Simons, P., and Macklin, A., 2014. The Governance Gap: Extractive Industries, Human Rights, and the Home State Advantage. Oxford: Routledge. 
Te Urewera Act 2014 (2014 No. 51) (New Zealand) [online]. Available from: http://www.legislation.govt.nz/act/public/2014/0051/latest/whole.html [Accessed 14 July 2018].

Thornton, J., 2000. Pandora's Poison: Chlorine, Health, and a New Environmental Strategy. Cambridge, MA: MIT Press.

United Nations Environment Programme, 2012. Global environment outlook GEO 5: Environment for the Future We Want [online]. Report. Nairobi: UNEP. Available from: http://www.unep.org/geo/ [Accessed 11 December 2018].

United Nations Environment Programme, 2015. Multiple Pathways to Sustainable Development: Initial Findings from the Global South [online]. Nairobi: UNEP. Available from: https://sustainabledevelopment.un.org/content/documents/1986MultiplePathway sSustainableDevelopment.pdf [Accessed 11 December 2018].

Valdivia, G., 2015. Eco-governmentality. In: T.A. Perreault, G. Bridge and J.P. McCarthy, eds., The Routledge Handbook of Political Ecology. Florence, KY: Taylor \& Francis, 467-480.

Verschuuren, B., et al., eds., 2010. Sacred Natural Sites: Conserving Nature and Culture [online]. London/Washington, DC: Earthscan. Available from: https://portals.iucn.org/library/sites/library/files/documents/2010-045.pdf [Accessed 11 December 2018].

Wacke, A., 2002. Protection of the Environment in Roman Law? Roman Legal Tradition [online], 1, 1-24. Available from:

https://romanlegaltradition.org/contents/2002/RLT-WACKE1.PDF [Accessed 11 December 2018].

Waters, C.N., et al., 2016. The Anthropocene is functionally and stratigraphically distinct from the Holocene. Science [online], 351(6269), aad2622. Available from: https://doi.org/10.1126/science.aad2622 [Accessed 11 December 2018].

Weston, B.H., and Bollier, D., 2013. Green Governance: Ecological Survival, Human Rights, and the Law and the Commons. New York: Cambridge University Press.

Williams, P., 2017. Factum of the Intervenor, Passamaquoddy Nation at Schoodic. Ktunaxa Nation v. British Columbia (Forests, Lands and Natural Resource Operations) [2017] 2 SCR 386 (Supreme Court of Canada) [online]. Available from: https://www.scc-csc.ca/WebDocumentsDocumentsWeb/36664/FM130 Intervener Council-of-the-PassamaquoddyNation-at-Schoodic.pdf [Accessed 17 December 2018].

Wood, M.C., 2009. Advancing the Sovereign Trust of Government to Safeguard the Environment for Present and Future Generations (Part I). Environmental Law [online], 39(1), 43-90. Available from: http://ssrn.com/abstract=1946078 [Accessed 11 December 2018].

Wood, M.C., 2013. Nature's Trust: Environmental Law for a New Ecological Age. Cambridge University Press. 
Woolley, O., 2014. Ecological Governance: Reappraising Law's Role in Protecting Ecosystem Functionality. Cambridge University Press.

Youngblood Henderson, J.S., Benson, M.L., and Findlay, I.H., 2000. Aboriginal Tenure in the Constitution of Canada. Toronto: Carswell.

Case law

Ashgar Leghari v Pakistan [2015] 25501 (Lahore High Court Green Bench) [online]. Available from: http://blogs2.law.columbia.edu/climate-change-litigation/wpcontent/uploads/sites/16/non-us-case-documents/2015/20150404 2015-W.P.-No.25501201 decision-1.pdf [Accessed 14 July 2018].

Beatriz Silvia Mendoza et al. $v$ National State of Argentina et al. (Damages resulting from environmental pollution of Matanza/Riachuelo river) [2008] M1569 (Supreme Court of Argentina) [online]. Available from: https://www.escr-net.org/docs/i/1469150 [Accessed 25 September 2015].

Case of the Saramaka People v Suriname [2007], Ser C 172 (Inter-American Court of Human Rights) [online]. Preliminary Objections, Merits, Reparations, and Costs Judgment. Available from:

http://www.corteidh.or.cr/docs/casos/articulos/seriec 172 ing.pdf [Accessed 14 July 2018].

Delgamuukw v British Columbia [1997] 3 SCR 1010 (Supreme Court of Canada).

Juliana v United States [2016] 6:15-CV-01517-TC (United States District Court for the District of Oregon Eugene Division) [online]. Available from:

http://blogs2.law.columbia.edu/climate-change-litigation/wpcontent/uploads/sites/16/non-us-case-documents/2015/20150404 2015-W.P.-No.25501201_decision-1.pdf [Accessed 14 July 2018].

Kichwa Indigenous People of Sarayaku v Ecuador [2012], Ser C 245 (Inter-American Court of Human Rights) [online]. Merits and Reparations Judgment. Available from: http://corteidh.or.cr/doc4s/casos/articulos/seriec 245 ing.pdf [Accessed 14 July 2018].

Ktunaxa Nation v British Columbia (Forests, Lands and Natural Resource Operations) [2017] 2 SCR 386 (Supreme Court of Canada) [online]. Available from: https://scccsc.lexum.com/scc-csc/scc-csc/en/item/16816/index.do [Accessed 14 December 2018].

Lovelace v Ontario [2000] 1 SCR 950 (Supreme Court of Canada) [online]. Available from: http://blogs2.law.columbia.edu/climate-change-litigation/wpcontent/uploads/sites/16/non-us-case-documents/2015/20150404 2015-W.P.-No.25501201 decision-1.pdf [Accessed 14 July 2018].

Manila v Concerned Residents of Manila Bay [2008] 171947-48 (Supreme Court of the Philippines) [online]. Available from: http://sc.judiciary.gov.ph/jurisprudence/2011/february2011/171947-48.htm [Accessed 25 September 2015]. 
Minors Oposa v Secretary of the Department of Environmental and Natural Resources [1993] 33 ILM 173 (Supreme Court of the Philippines) [online]. Available from:

http://blogs2.law.columbia.edu/climate-change-litigation/wpcontent/uploads/sites/16/non-us-case-documents/2015/20150404 2015-W.P.-No.25501201_decision-1.pdf [Accessed 14 July 2018].

Ngati Rangi Trust v Manawatu-Wanganui Regional Council [2004] A067/2004

(Environmental Court of New Zealand).

Orissa Mining Corporation Ltd. v Ministry of Environment and Forest, et al. [2013] 6 SCR 881 (Supreme Court of India) [online]. Available from:

https://indiankanoon.org/doc/153831190/ [Accessed 14 July 2018].

The Netherlands v Urgenda [2018] C/09/456689/ HA ZA 13-1396 (The Hague Court of Appeal) [online]. Available from:

https://uitspraken.rechtspraak.nl/inziendocument?id=ECLI:NL:GHDHA:2018:261 0 [Accessed 14 December 2018].

Tsilhqot'in Nation v British Columbia [2014] 2 SCR 257 (Supreme Court of Canada).

Urgenda $v$ The Netherlands [2015] C/09/456689/HA ZA 13-1396 (District Court of the Hague), Upheld on Appeal [online]. Available from:

https://uitspraken.rechtspraak.nl/inziendocument?id=ECLI\%3ANL\%3ARBDHA \%3A2015\%3A7196 [Accessed 14 July 2018].

Wheeler c. Director de la Procuraduria General Del Estado de Loja [2011] 1121-2011-0010

(Corte Provincial de Justicia de Loja-Sala Penal).

Wisconsin v Environmental Protection Agency, et al. [2001] 266 F3d 741, 535 US 1121

(United States Court of Appeals, Seventh Circuit). 